\title{
Emotional Intelligence and Adjustment to Community Living Among Consecrated Women Religious in Karen, Nairobi, Kenya
}

\author{
Lucia Mwikali. K. Mutuku, Stephen Asatsa (PhD), Josephine Adibo (PhD) \\ Department of Psychology, The Catholic University of Eastern Africa
}

\begin{abstract}
The Congregation for the Institutes of Consecrated Life and Societies of Apostolic life (CICLSAL) views the issue of Consecrated Women abandoning religious life after initial stages of formation as an emotional crisis from remote disappointments caused by an inauthentic religious community living. Failure to adjust is experienced to cause anxiety related feelings among other mental health related challenges. The study used sequential explanatory mixed research design. The study equally used census to collect data from all the 138 participants of various programs in AOSK-Chem Chemi ya Uzima Institute as per 2020 enrollment. The study was guided by cognitive behavior theory by Aaron Beck, (1960), complemented by Emotional Intelligence theory by Daniel Goleman, (1995). A Modified Emotional Intelligence Questionnaire (MEIQ) based on Daniel Goleman's Emotional intelligence, as modified by Suzanne Farmer et al., (c.2013) was used to measure the level of Emotional Intelligence. Adjustment to community living was measured using modified sub-scales; Emotional Maturity, Satisfaction with life, and SelfEfficacy Scales. Data were analyzed using correlation and regression analysis in order to establish the extent to which each of the variables contributed to adjustment in community living. The findings reveal the overall Emotional Intelligence to have had a strong significant positive correlation with the overall adjustment to community living among Consecrated Women Religious. The finding implies that an increase in emotional intelligence would lead to a corresponding increase in adjustment to community living. Emotional Maturity was found to be a significant function of Self-awareness and selfmanagement while Life satisfaction was also found to have a significant relationship with social-awareness. Linear regression findings indicate significant weak positive relationship between adjustment to community living with social awareness. This reveals that Consecrated Women Religious need to improve their relational domain to enjoy smooth adjustment to community living.
\end{abstract}

Key Words: Emotional Intelligence; Consecrated Women Religious; Community Living

\section{BACKGROUND}

$\mathrm{C}_{\mathrm{R}}^{\mathrm{o}}$ onsecrated life is a historical and theological reality in the Roman Catholic Church (Appiah-Kubi, 2019). It is viewed by The Congregation for the Institute of Consecrated Life and Societies of Apostolic Life (CICLSAL, 2007) as a "gift of the Spirit". The Roman Catholic Church regards certain elements as essential to Consecrated life, such as a stable form of community life, among others (Magisterium on Religious life, 1983). Those Women called to Consecrated life referred in this context as 'Consecrated Women Religious (CWR)' and understood in layman's language as 'Nuns' believe that they respond to God's call, whom they believe is the initiator of their call. They consecrate themselves to Him through the profession of the evangelical counsels of Chastity, Poverty, and Obedience by public vow and commit themselves to live in a community.

In a global message to all religious men and women, The Congregation for the Institutes of Consecrated Life and Societies of Apostolic Life (CICLSAL) views the issue of Consecrated women abandoning religious life after initial stages of formation as an emotional crisis from remote disappointments caused by an inauthentic community living (New wine in new wineskin, 2017). This is a gap that need to be addressed to empower individual Consecrated Women with life coping skills that integrate their shadow self. Cardinal Donald Wueri's reflection during an opening Mass (Eucharistic celebration) for the year of consecrated life in the Archdiocese of Washington (February, 2015) supported the idea that religious life is a social unit, a family of its kind where challenges can emerge that could need a level of selfawareness and emotional management for smooth adjustments, for one who has to enjoy communal life and the gift of her vocation. In some cases, some of the disappointments and frustrations arise when issues to do with equality and provision of equal opportunities arise among Consecrated Women Religious.

In a study that examined social adjustment problems among mixed school-going academic achievers in India, (Srivastava, 2018) noted a need to promote gender equality and the provision of equal opportunities in matters pertaining to educational and emotional development. Along with these findings, are the issues of equality and provision of equal opportunities among Consecrated Women Religious. This is experienced as a very sensitive issue that create visible gaps between the highly educated and not highly educated, the 'whites' and the 'Africans,' the 'Senior sister and the Junior' between tribe 'A' and tribe 'B' and between who has 'authority over who?' In another study, (Ahmad, Anwar \& Khan, 2017) confirms the importance of having high self-efficacy levels for significant better social adjustment. In reference to this adjustment for a CW with low self-efficacy in community is likely to be challenging simply because her perception of her 
abilities is assumed to play a key role in her adjustment. These realities have been experienced to trigger different emotions depending on individuals past experiences. This is why the researcher assumes that Emotional Intelligence could be a helpful tool to help Consecrated Women Religious to adjust better in their community living.

In a related qualitative study, (Newsome \& Cooper, 2016) examined international students' cultural and social experiences in their institutional community in British Universities away from their motherland. Data was collected through case studies and semi-structured, in-depth informant style interviews. The findings reflect frustrated initial expectations and serious cultural shock that required a lot of adjustments. The findings also show that many students managed to adjust while others chose to drop out. These findings confirm the researcher's experiences while interacting with Consecrated Women in Chemchemi ya Uzima Institute (CCUI), where they expressed how they never thought they would have to struggle in dealing with themselves and how they struggle to accept the reality of their differences and the tensions involved. This was seen to frustrate their initial expectations of consecrated life.

In relation to the above study, Consecrated Women Religious express how they least expected the kind of conflicts and unnecessary tensions they experience as they deal with their inner journey while embracing community life. Some Consecrated Women Religious expressed the pains they go through adjusting to community life demands, which has left them with repressed unresolved issues. This study attempted to address adjustment gap by examining if Emotional Intelligence could address maladjustment issues in community life. In addition

(Ahmad et al., 2017) in their study in Pakistan, confirms the importance of having high self-efficacy levels for significant better social adjustment. Adjustment for a Consecrated Women Religious with low self-efficacy in CCUI is likely to be challenging simply because her perception of her abilities is assumed to play a key role in her adjustment.

In examining the influence of family background on social adjustment of adolescents in Nigeria, (Kpan-Idiok \& Ackley,2018) found out that family structures, family type, family size, and parental attitudes significantly influence social adjustment. Understanding Consecrated Women in a family context makes sense to the researcher in an attempt to understand their issues. The religious community provides the context through which every Consecrated Woman lives out her life commitment and remains central to any authentic form of religious lifestyle (Eze, 2012). Consequently, every Consecrated Woman is a product of her family, which she leaves behind to join another social group identified in 'Vita Consecrata' as a consecrated religious family (Paul II, 1996). In this new family, a process of individual integral development begins through intensive religious formation, to prepare Consecrated Women to live authentic community living, since religious life is a communal life lived in a community, and community life is central to any authentic form of religious lifestyle (Schrein,2017). However, according to (Eze,2012), many Consecrated Women Religious suffer from sadness and depression caused by frustration from community life demands. In another study (Eze, Lindegger \& Rokoczy,2016) found that many young religious do not feel at home in religious communities in connection to personal interactions with others in the community which for the researcher is a sign of emotional maturity deficiency.

The researcher has observed that most of the frustrations and consequent emotional pains experienced by individuals in the religious community is triggered by past experiences. This is supported by various studies on practical issues that affected Consecrated Women in their community living (Van Deusen, 2009; Nyawira et al., 1998; Okure, 2010; Eze, Lindegger \& Rakoczy, 2016). As a result, the researchers reported that religious communities' structures seemed designed to make adults keep acting like children (Eze et al., 2016). This is why this study is considered important and assumed to be a useful tool to help CWR in their journey towards integration and homeliness.

Although community life issues have been addressed by major superiors in their respective assemblies globally on the need to improve fraternal life quality among consecrated women religious communities, a study that was carried out through the initiative of Association of Consecrated Women of Eastern and Central Africa (ACWECA, 2014) found that some members have experienced deeper emotional wounds.

In their 17th plenary assembly held in Tanzania 2017, the Association of Consecrated Women in Eastern and Central Africa (ACWECA, 2017) explored the causes of the high numbers of departure from consecrated life both after initial formation and in advanced age despite the intensive religious formation. In an attempt to unravel this phenomenon, the women religious leaders noted that, apart from the affective crisis, the cognitive dissonance that existed between elderly and young Consecrated Women Religious, power-related issues, disappointments with community life without authenticity, seem to have contributed to emotional turbulence among Consecrated Women Religious, thus affecting the quality of life together.

In a study that supported the assumption that Emotional Intelligence plays a key role in adjustment to community living, (Ngari, 2014) stated that 'employees' with a high level of Emotional Intelligence perform better and are satisfied in their job than those with low levels, which was also asserted by (Mwathi, 2010) and (Omondi, 2016). Similarly, high levels of Emotional Intelligence for a Consecrated Women Religious could be a credit since she is likely to be very balanced in her self-awareness and awareness of her environment. On the other hand, low levels of Emotional Intelligence could lead to a lack of sensitivity towards the emotions of other Consecrated Women Religious 
in her community, which may cause unnecessary conflicts. This study is crucial in its attempt to identify if there could be a relationship between Emotional Intelligence and adjustment to community living among Consecrated Women Religious in CCUI.

The Association of Sisterhoods of Kenya (AOSK) has established Chem Chemi ya Uzima Institute (CCUI) as one of its institutions that provide opportunities for Consecrated Women Religious (CWR) to nurture the vitality of their religious vocations. Consecrated Women Religious converge in CCUI for inter-congregational on-going formation and renewal programs, thus forming a dynamic intercultural community. In this community setup, Consecrated Women Religious find themselves making necessary adjustments, to mold their behavior, values, attitudes, and core belief systems in order to create a sense of belonging despite the cultural diversity. Failure to adjust may lead to anxiety related feelings such as frustrations, insecurity and fear of the unknown which can be disruptive thus affecting the quality of community life.

\section{METHODS}

The study adopted an explanatory sequential mixed research method design. This means, a combination of quantitative and qualitative method done in two phases. The rationale for this approach is that, more analysis specifically through qualitative data collection was needed to refine, extend and explain the general picture of the problem that the quantitative data results provided (Subedi, 2016). Research design is a type of inquiry within a research approach that provides direction for procedures in a particular method used to gather data (Ishtiaq, 2019; Creswell, 2014). In the context of this study, the researcher intended to investigate possible relationship between EI and adjustment to community living among Consecrated Women Religious in two phases to obtain a well refined and reliable picture of the situation in the community that helps to determine the type of interventions. Qualitative data comes in to explain reality from a different perspective. The mixed research method is known for its rigorous procedures in conducting both quantitative and qualitative research. The method is also known for its integration of findings from quantitative results and qualitative findings (Creswell, 2014). The process of data collection involved first collecting quantitative data, analyzing the data, and then building on the obtained results to plan the second phase, which was be a qualitative phase (Ishtiaq, 2019).

In phase one, questionnaire for collecting quantitative data were distributed by the researcher to all the 138 participants who were given one week to respond to it. This data was analyzed by the researcher and research assistant. Obtained results were explained further through qualitative phase. Ten (10) respondents were purposely selected using maximum variation methodology of age, religious profession and levels of education to ensure heterogeneity in the responses. In phase two, qualitative data was collected through the individual's in- depth interviews to explain further the results from phase one. The research was conducted in AOSK- Chem Chemi ya Uzima Institute (CCUI) located in the Suburb of Karen in Lang'ata constituency, Nairobi County. This institution was considered to have a very high representation of Consecrated Women Religious from different religious communities. The institution equally offered a good representation of the different categories of population of CWR in terms of diversity in age range, adjustment experiences both in personal life and in the religious community life. It was thus the estimation of the researcher that CCUI was a fair representation of Consecrated Women Religious Congregations in the Catholic Church.

The target Population of the study was a total of 138 participants according to 2020 academic year enrolment statistics of the institution. The study targeted participants who were categorized in three groups according to the nature of their programs, 57 formators under training, 58 participants of academic programs, and 23 participants of the psychospiritual renewal (sabbatical) program. Participants were known to come from 22 different nationalities and from 47 different women religious congregations.

In choosing this target population, the researcher noted the diversity of age variation of participants ranging from 20 to 70 years of age. The researcher looked at age differences as very key in exploring the relationship between Emotional Intelligence and adjustment in community living, especially the experiences of Consecrated Women Religious in their various stages of life. Due to the small number of the target population, the study used census as a sampling strategy. Census ensured that all the 138 Consecrated Women Religious from various programs in CCUI participated in this study; participants of training of formators program, participants undergoing academic program and participants of psycho-spiritual renewal sabbatical program.

\section{Research Instrument}

Emotional intelligence was measured through a modified Emotional Intelligence questionnaire by Suzanne Farmer et al., (2013), while adjustment to community living was measured through 3 modified subscales: Emotional Maturity Scale (EMS), Satisfaction with Life Scale (SWLS), and New Self Efficacy Scale (NSES), which were developed by Signh and Bhargava (1991), Diener et al. (1985) and Chen et al. (2001) respectively. These are identified to be the key indicators of adjustment in a community living in this study. The tools reported high internal consistency in this study. The reliability coefficients of various domains of the tools are shown in Table 1. Interviews were also conducted to explore various ways of enhancing adjustment to community living. 
Table 1: Reliability of Research Instruments

\begin{tabular}{|c|c|c|c|}
\hline Scale & Sub-Scale & Number of items & $\begin{array}{c}\text { Cronbach's } \\
\text { Alpha }\end{array}$ \\
\hline $\begin{array}{c}\text { Emotional } \\
\text { Quotient }\end{array}$ & 30 & 0.874 \\
\hline & $\begin{array}{c}\text { Personal } \\
\text { Domain }\end{array}$ & 15 & 0.775 \\
\hline $\begin{array}{c}\text { Relational } \\
\text { Domain }\end{array}$ & 15 & 0.804 \\
\hline $\begin{array}{c}\text { Adjustment to } \\
\text { community living }\end{array}$ & $\begin{array}{c}\text { Emotional } \\
\text { maturity }\end{array}$ & 5 & 0.780 \\
\hline & $\begin{array}{c}\text { Life } \\
\text { satisfaction }\end{array}$ & 5 & 0.702 \\
\hline & $\begin{array}{c}\text { Self- } \\
\text { efficacy }\end{array}$ & 5 & 0.795 \\
\hline
\end{tabular}

Note: According to Cronbach (1951), an alpha $(\alpha)$ in the range $0.7 \leq \alpha<0.9$ indicates good internal consistency of the data collection instrument.

\section{Ethical Consideration}

In this study, ethical clearance was obtained from ethical review board of the Catholic University of Eastern Africa, followed by research license from the National Commission for Science and Technology (NACOSTI), Kenya. According to (Marshall and Rossman, 2011), ethical guidelines bind every researcher, a practice that increases the trustworthiness of the study. Consent from the institution and individual participants was sought before administering the questionnaires.

The researcher ensured that respect for the respondents was observed, and anything that would put any of them at risk was carefully guarded against (Creswell, 2009). Coding of response was employed to assure anonymity, and the respondents were not expected to disclose their identities.

\section{RESULTS}

Relationship between emotional Intelligence dimensions and adjustment to community living

The Pearson's correlation matrix summarized in Table 2 shows that there was significant correlations among all the dimensions of emotional intelligence and adjustment to community living at $\alpha=.05$. For instance, the study found the overall Emotional Intelligence to have a strong significant positive correlation with the overall adjustment to community living $(\mathrm{r}=.598, \mathrm{p}<.01)$. Self-awareness $(\mathrm{r}=.454)$ and selfmanagement $(\mathrm{r}=.434)$ were found to have a weak significant positive correlation with adjustment to community living while Social awareness $(\mathrm{r}=.541)$ and relationship management $(\mathrm{r}=.526)$ were found to have a strong significant positive correlation with adjustment to community living. The findings reveal clearly relational domain $(\mathrm{r}=.593, \mathrm{p}<.001)$ to have a strong significant positive correlation with adjustment to community living than personal domain self -assessment( $\mathrm{r}=.490, \mathrm{p}<.001$. The overall findings imply that an increase in emotional intelligence would lead to a corresponding increase in adjustment to community living.

However, Emotional Maturity was found to have a weak significant positive correlation with self-management $(\mathrm{R}=.470, \mathrm{p}<.001)$ compared to Self-Awareness $(\mathrm{r}=.508$, $\mathrm{p}<.001)$, Relationship Management $(\mathrm{r}=.527, \mathrm{p}<.001)$, and Social Awareness ( $\mathrm{r}=.520, \mathrm{p}<.001)$ which have a strong significant positive correlation, as summarized in Table 2 . This implies that growth in the various dimensions of Emotional Intelligence would lead to emotional maturity.

Table2: Correlation between Emotional Intelligence dimensions and Adjustment to Community Living

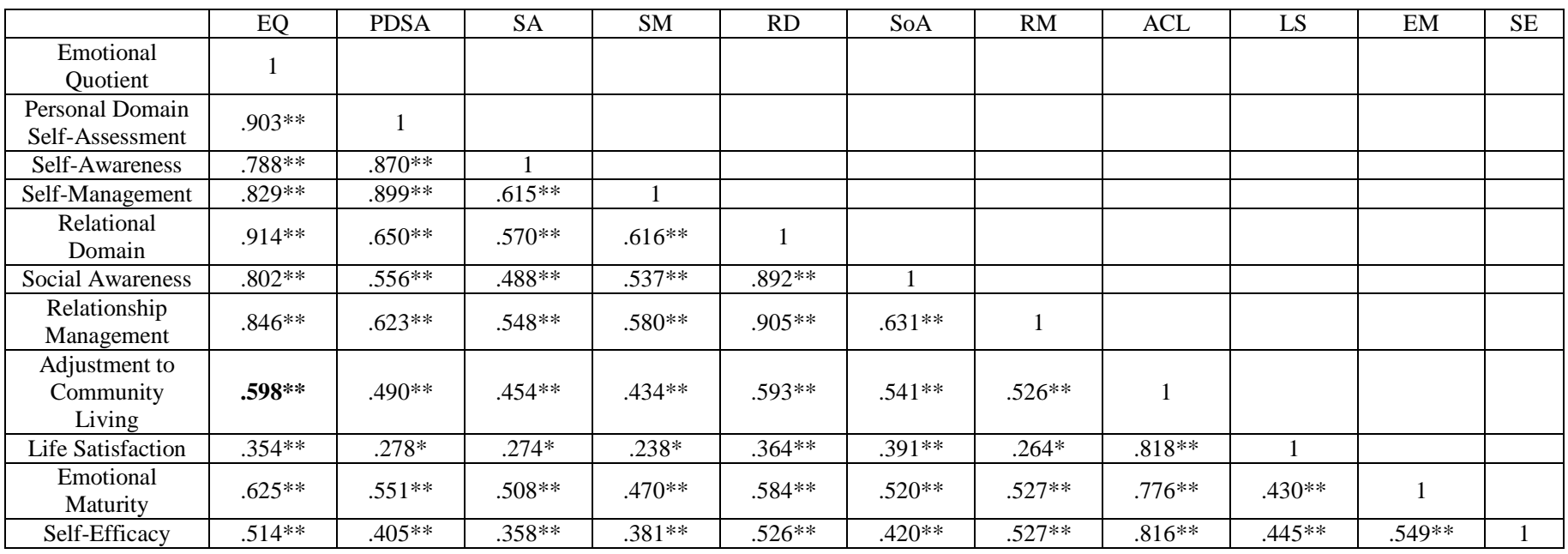

Note: Sample size $(n)=120 ; *$ means correlation is significant at $\alpha=.05 ; * *$ means correlation is significant at $\alpha=.01$

The finding confirms how emotions are important aspects of human behavior and it is closely related to quality of adjustment lived by Consecrated Women in their unique personality. The findings further confirm that individual 
Consecrated Woman's experience of emotions differ from each other and some have emotional maturity with the ability to adapt to community life challenges while others seem to suffer and struggle adapting to social issues of their surroundings. The results in this study indicating the presence of a significant positive correlation among all dimensions of EI and adjustment to community living can be attributed to a variety of reasons. It could be attributed to the quality of the programs offered in Chem Chemi ya Uzima Institute that are geared towards inner journey for personal transformation. It may be attributed to the emotions, whether positive or negative and their level of self-management and awareness of their need for social skills that motivate a Consecrated Woman Religious in managing her relationships for healthy adjustments in the community. Consequently, availability of Emotional Intelligence for a CWR helps her to embrace basic and important values which help her adjust to community life set of norms for a satisfying consecrated life.

\section{Regression Analysis}

A hierarchical regression analysis involving linear regression and likelihood parameter estimation from the analysis of covariance (ANCOVA) was used to check the impact of Emotional Intelligence on the adjustment to community living. The first step involved linear regression analysis to check the relationship between Emotional Intelligence and adjustment to community living $(\mathrm{B}=.689, \mathrm{p}<.001)$. The study also found that Emotional Intelligence explained $35.2 \%$ of the total variations in the adjustment to community living (Adjusted $\mathrm{R}^{2}=.352$ ); which is a highlight of the importance Emotional Intelligence has on adjustment to community living.
All the linear regression assumptions for normality, multicollinearity and autocorrelation were tested as shown in Table 3. The results of the linear regression indicates that Emotional Intelligence helps in self-motivation when facing challenges and frustrations while setting the mood and maintaining clear thinking with ability to empathize. In other words, the results of Model 1 of Table 3 show that the consecrated women with high Emotional Intelligence tend to adjust adequately to community living while the converse is true as well.

The study further assessed the relationship between the dimensions of Emotional Intelligence and dimensions of adjustment to community living. The results of Table 3 indicate significant weak positive relationship between adjustment to community living with social awareness $(\mathrm{B}=.282, \mathrm{p}<.05)$ and relationship management $(\mathrm{B}=.198$, $\mathrm{p}<.05)$. These two dimensions are the relational domains of Emotional Intelligence. This means that religious consecrated women need to improve their relational domain to enjoy smooth adjustment to community living.

Life satisfaction was also found to have significant relationship with social-awareness $(\mathrm{B}=.484, \mathrm{p}<.05)$. This implies that nuns with high levels of social-awareness tend have high life satisfaction. Moreover, Emotional Maturity was found to be a significant function of Self-awareness $(B=.226$, $\mathrm{p}<.05)$ and social-awareness $(\mathrm{B}=.227, \mathrm{p}<.05)$. Lastly, the study found self-efficacy to be significantly influenced by relationship management $(\mathrm{B}=.423, \mathrm{p}<.05)$ as summarized in Table 3.

Table 3: Linear regression analysis indicating the impact of the dimensions of Emotional Intelligence on Adjustment to Community Living and its dimensions

\begin{tabular}{|c|c|c|c|c|c|c|c|c|}
\hline \multirow[t]{2}{*}{ Predictor variables } & \multicolumn{2}{|c|}{$\begin{array}{l}\text { Adjustment to Community } \\
\text { Living }\end{array}$} & \multicolumn{2}{|c|}{ Life Satisfaction } & \multicolumn{2}{|c|}{ Emotional Maturity } & \multicolumn{2}{|c|}{ Self-Efficacy } \\
\hline & B & p-value & B & p-value & B & p-value & B & p-value \\
\hline Self-Awareness & 0.151 & 0.116 & 0.17 & 0.295 & $0.226^{*}$ & 0.021 & 0.058 & 0.641 \\
\hline Self-Management & 0.045 & 0.648 & -0.021 & 0.899 & 0.083 & 0.401 & 0.072 & 0.574 \\
\hline $\begin{array}{l}\text { Relationship } \\
\text { Management } \\
\end{array}$ & $0.198^{*}$ & 0.035 & -0.016 & 0.919 & 0.184 & 0.052 & $0.427 *$ & 0.001 \\
\hline \multicolumn{9}{|l|}{ Assumption tests } \\
\hline $\mathrm{R}^{2}$ & 0.371 & & 0.162 & & 0.385 & & 0.296 & \\
\hline Adjusted $\mathrm{R}^{2}$ & 0.349 & & 0.133 & & 0.364 & & 0.272 & \\
\hline
\end{tabular}

Note: Dependent variable: Dimensions of Adjustment to Community Living; B is the unstandardized regression coefficient representing the amount of change in the dependent variable due to a change of 1 unit of the independent variable; * means significant at $\alpha=.05$. Durbin-Watson test statistic between $1.5-2.5$ indicates no autocorrelation of the residuals. The $\mathrm{VIF}<10$ indicates no multicollinearity among the predictor variables. 


\section{Community Living Adjustment Strategies}

The study sought to explore various ways through which community living adjustment could be enhanced among nuns. Interviews were conducted from 10 participants and their views summarized in themes as shown in Table 4.

Table 4: Strategies to enhance adjustment to community living among Consecrated Women

\begin{tabular}{|c|c|c|}
\hline Interviewees Opinion & $\mathrm{F}$ & $\%$ \\
\hline $\begin{array}{l}\text { Emotional intelligence in religious formation syllabus: To } \\
\text { strengthen and heal relationships, the communities should } \\
\text { devise ways of ensuring that the CW improve on their } \\
\text { self-acceptance; empowered in self-awareness through } \\
\text { personal reflections/openness with the self; understanding } \\
\text { of others' cultural and family backgrounds, hence devising } \\
\text { one-on-one talks especially with young members who are } \\
\text { new in the community to enhance emotional self-care }\end{array}$ & 9 & 90 \\
\hline $\begin{array}{l}\text { Spiritual Intelligence for integration: Consecrated Women } \\
\text { to revisit their spiritual sources to discover their real } \\
\text { identity and needs. Recognition of one's inner values, } \\
\text { explore new values as they search for meaning in their } \\
\text { lives and the main purpose for being in a religious } \\
\text { community. Consecrated Women to explore and use their } \\
\text { inner spiritual sources to obtain flexibility and tolerance } \\
\text { with challenging community issues. Ability to give } \\
\text { meaning to events seeking higher level of satisfaction. }\end{array}$ & 7 & $70 \%$ \\
\hline $\begin{array}{l}\text { Financial sustainability: To address major gaps, that is the } \\
\text { fear to be innovative and creative. Investments and } \\
\text { networking among congregations. Let each member of the } \\
\text { community understand their financial constrain. Let } \\
\text { leaders think together with members on the best strategy } \\
\text { to deal with financial challenges. Members to educate } \\
\text { their families on their limitations in supporting them } \\
\text { financially. Dealing with donor dependency frustrations. }\end{array}$ & 6 & $60 \%$ \\
\hline $\begin{array}{l}\text { Empowerment through education: Let superiors empower } \\
\text { sisters through education as a way of boosting their self- } \\
\text { esteem and to enhance financial status in community. }\end{array}$ & 2 & $20 \%$ \\
\hline $\begin{array}{l}\text { Human resource management: Empower leaders on } \\
\text { management of human resource since member are reliable } \\
\text { resources. }\end{array}$ & 2 & $20 \%$ \\
\hline
\end{tabular}

From the statements, it is clear that the consecrated women are willing to change their situation and develop high emotional intelligence that will lead to high adaptation to community living. As such, the communities should devise ways of ensuring that the consecrated women improve on their self-acceptance; empowered in self-awareness through personal reflections/openness with the self; understanding of others' cultural and family backgrounds, hence devising oneon-one talks especially with young temporary professed who are new in the community.

Some of the interviewees expressed how they would wish community members to be exposed to self-awareness, self-management, social awareness and relationship management as early as they join the religious community to enhance self-knowledge and emotional self-care. In support of the above expressed wish, one of them stated, "This will create an opportunity to face ones realities early especially those related to unresolved childhood issues" (Sr.A, personal communication, May 1, 2021)..

From the interview, a gap in self- awareness was noticed to exist between those who have had an opportunity to go through self-awareness programs and the rest of members and yet they live in the same community. One of them expressed, "there is a need to realise that community members are not at the same level and that is why we crush in ideas and perception, this is why we need to learn to offer understanding and empathy to each other" (Sr. I, personal communication, May 7, 2021).

It was noted that during the interview the respondents shared their personal experiences in detail and referred as well to experiences of community members that affected their lives together. This is supported by a statement made by one of the interviewees. She voiced, "Sisters have really issues but they don't know how to address them, they fear being betrayed" (Sr. A, personal communication, May 1, 2021). This kind of fear may require restructuring of one's thoughts through a cognitive behavioural approach which (Corey, 2008) considers to be an effective approach to therapy due to its emphasis on helping an individual with selfmanagement skills.

Another point proposed that will mitigate adjustment issues in community is for sisters to make use of spiritual intelligence resources to discover their real identity and needs. Out of 10 interviewees, 7 (70\%) proposed spiritual intelligence for integration. One of them voiced her observation, "I have observed that many of us are carried away by work and most of the time go for prayer to fulfil the duty since it is in the timetable when the body cannot concentrate. Such a person will either be seen restless because the body communicates a different need or is asleep throughout meditation." (Sr. C, personal communication, May 2, 2021). It is quite clear that such a Consecrated Woman need to revisit her religious values and seek for assistance to ensure she does not compromise her prayer life.

A good number of participants articulated these statements at different times in attempt to respond to possible strategies to enhance adjustment in community living; 'there is a need to search for meaning in my life', 'is my value in doing or being?' 'Un-reflected life is not worth living'. '...I think my spiritual life will give meaning to my life crisis'. This is supported by an experience from one of the participants interviewed. Sr. D expressed her struggle that makes her realise her need for spiritual intelligence,

I am one of those who have not been happy in my religious community, I have always blamed others for my miserable state of being. I am realising how I compromised my religious values. Until I attended a workshop on spiritual discernment that hit me hard' I thought I was okay. I now concur with the words of St Augustine when he stated 'our hearts are restless until they rest in God (a higher being)' who gives 
meaning to our experiences" (Sr. A, personal communication, May 1, 2021).

\section{DISCUSSION}

The findings of this study related with other studies globally. The study found that Emotional Intelligence influences community living adjustment. This is emerging to be of interest within various disciplines and in religious life as a way of life. In this context, Emotional Intelligence is the ability of a Consecrated Women to be emotionally self-aware, with the ability to be in-charge and manager of her strong emotions, while being sensitive and emphatic to others for healthy relationship management as they cope with standards, values, and needs of a society in order to be accepted (Kumar, 2018). Therefore, Emotional Intelligence dimensions of selfawareness, self-regulation, social awareness and relationship management are assumed to be key if a Consecrated Woman has to adjust well in her community.

In Poland, (Smieja, Mrozowicz-wronska, \& Kobylinska, 2011) explored whether people with different levels of EI apply different strategies of emotional regulation in a study that sampled 349 undergraduate students (227 women and 122 men). He used the Emotional Intelligence test (EIT) (Smieja et al., 2007) to collect data, and the (ERQ) emotional regulation questionnaire (Gross and John, 2003) to test emotional regulation. Findings show a significant relationship between emotional abilities and emotional regulation. However, analysis of the interaction between gender and Emotional Intelligence reveal that men seem to use suppression more often than women and this difference was highly significant $\mathrm{t}(343)=5.62, \mathrm{p}<.0001$ and emotionally unintelligent men are noted to suppress emotion more than women and compared with men with high levels of EI. The findings supported the assumption that emotional selfregulation plays a key role in adjustment.

Similar findings were obtained in a study by Almajali et al. (2016) done in Jordan university that persons with high levels of Emotional Intelligence have selfconfidence, purpose in life, adjusts and adapts easily in their environments. Katanani (2018) and Jain (2015) noted that one who is aware of herself is able to pay attention to how others influence her emotions, thus making it easier to form healthy interpersonal relationships consequently able to set life goals.

Sharma (2019) explored adjustment in relation to Emotional Intelligence, spiritual intelligence, and life satisfaction among professional and non-professional working and non-working women of Punjab. A systematic sampling procedure was used to sample 280 professionals and 250 nonprofessionals. Data was collected with Bell adjustment inventory adapted by the investigator, Emotional Intelligence scale, and spiritual intelligence and life satisfaction scale. The coefficient of correlation of adjustment with Emotional Intelligence as well as spiritual intelligence is negative and significant $(r=0.127, p<0.01)$ for the professional group
(280) and $(\mathrm{r}=0.180, \mathrm{p}<0.01)$ According to the findings, the researchers noted that an emotionally adjusted woman could handle the stress, depression, anxiety and other mental tensions in a better way as compared to emotionally maladjusted women. The researcher pointed out the role of proper use of psychological variables such as emotional selfawareness on improving women's adjustment levels (Sharma, 2019).

The findings of this study agrees with (Jain, 2015) on relationship between Emotional Intelligence and Life satisfaction which revealed a significantly positive relationship between the two variables. It is therefore clear that, managing their emotions well, Consecrated Women will easily face a number of challenges in their community life and move towards life satisfaction. ( Kadiyono \& Hafiar, 2017) concurred with this findings in their discovery that, persons with high levels of emotional intelligence adjust better and possess the ability to adapt easily in their environment.

\section{REFERENCES}

[1] ACWECA), (2014). African Culture and Religious women. Kenya, CUEA Press.

[2] ACWECA, (2017). 17th Plenary Assembly report, Tanzania.

[3] Ahmad, M., Anwar, M. N., \& Khan, S. (2017). Social adjustments and Self-efficacy of University Students. Humanities and Social Sciences, 24(2), 13.

[4] Akpan-Idiok, P., \& Ackley, A. (2018). Influence of Family Background on Social Adjustment of Adolescent Students of Southern Senatorial District of Cross River State, Nigeria. International Journal of Humanities Social Sciences and Education, 5(8), 227-243.

[5] Almajali, H. K., Saraireh, A. N. S., Mohammad, A., Bendania, L., \& Katanani, H. J. K. (2016). Emotional Intelligence and its relation to Social and Psychological adjustment among the Students of the University of Jordan. 52, 19.

[6] Appiah-Kubi, F. (2019). Magisterium: Essential and Constitutive Element of the Church's Life and Mission in the light of the SecondVaticanCouncil.2432.Https://Doi.Org/10.32051/06241903.

[7] Corey, G. (2008). Theory and Practice of Counseling and Psychotherapy. Cengage Learning

[8] Creswell, J. W. (2014). Educational research: Planning, conducting, and evaluating quantitative and Qualitative research ( 4th Ed.). Boston, MA: Pearson

[9] Eze, C, Gc Lindegger, \& Rakoczy, S. (2016). Power Relations Influencing Catholic Religious Sisters' Identity Construction: A Study of Inter-subjective Exchange in Religious Community Living. International Journal of Social Science Studies, 4(5), 104119.

[10] Eze, Chika. (2012). Identity construction of Roman Catholic religious sisters in the church in Nigeria.

[11] Ishtiaq, M. (2019). Book Review Creswell, J. W. (2014). Research Design: Qualitative, Quantitative and Mixed Methods Approaches (4th ed.). Thousand Oaks, CA: Sage. English Language Teaching, 12, 40. https://doi.org/10.5539/elt.v12n5p40

[12] Jain, D. (2015). Emotional Intelligence \&amp; its relationship with Life Satisfaction. https://doi.org/10.13140/RG.2.1.3693.6802

[13] Jane, M. W. (2020). Emotional Intelligence and academic selfEfficacy beliefs as predictors of academic achievement among form four students in Kiambu County, Kenya (Doctoral Dissertation, School of Education, Kenyatta University).

[14] Kadiyono, A., \& Hafiar, H. (2017). The role of academic selfmanagement in improvingstudents'academicachievement.117120. https://doi.org/10.1201/9781315166575-30 
[15] Katanani, H. (2018). Emotional Intelligence and its relation to Social and Psychological adjustment among the Students of the University of Jordan. European Journal of Social Sciences, 52.

[16] Kumar, N., Bhati, H. \& Sharma, V. (2017). Counselling for community wellbeing and happiness. Indian Journal of health and wellbeing. 8(6), 492-494.

[17] Mwathi, K. B. (2010.). Relationship Between Emotional Intelligence And Job Performance Among Service Providers In Rehabilitation Schools In Kenya. Journal article 159.

[18] Newsome, L. K., \& Cooper, P. (2016.). International Students' Cultural and Social Experiences in a British University: "Such a hard life [it] is here". Journal of international students, 21. Volume 6, Issue 1, pp. 195-215. http://jistudents.org

[19] Ngari, J. M. K. (2014). Effects of Emotional Intelligence on Employee Performance in the Hotel Industry in Kenya.

[20] Omondi, G. A. (2016). Influence Of Manager's Emotional Intelligence On Employee Job Satisfaction At The Kenya Post Office Savings Bank. 75. Thesis, University of Nairobi

[21] Sharma, M., Kumar, S., \& Joshi, H. L. (2012). Self-Efficacy and Adjustment among Adolescents. Indian Journal of Positive Psychology, 3(2), 156.

[22] Sharma, S. (2019). A Co-Relational Study of Adjustment among Professional and Non-Professional Working Women with respect to Psychological Variables. International Journal of Recent
Technology and Engineering (IJRTE) ISSN: 2277-3878, Volume8 , Issue- $1 \mathrm{C} 2$

[23] Singh, S., \& Sharma, N. R. (2018). Self-regulation as a correlate of psychological well-being. Indian Journal of Health \& Wellbeing, 9(3), 441-444.

[24] Smieja, M., Mrozowicz-Wronska, M., \& Kobylinska, D. (2011). Emotional Intelligence And Emotion Regulation Strategies. Studia Psychologiczne, 49, 55-64. https://doi.org/10.2478/v10167-0100040-x

[25] Schrein, S. (2017). Religious Life in the 21st Century: The Prospect of Refounding. By Diarmuid O’Murchu . Maryknoll, NY: Orbis Books,

[26] Souci, D.,Kamara, M., Nyawira, N., \&Grebalet, P. (2008).Yung religious association of Kenya-Survey 1996.In Religious Formation in International Communities, 6, 8-33.

[27] Srivastava, P. S. (2018) Social adjustment problems of school going academic achievers. international journal of Academic research development. Issue 1; pp 164-166

[28] Subedi, D. (2016). Explanatory Sequential Mixed Method Design as the Third Research Community of Knowledge Claim. American JournalofEducationalResearch,4,570577.https://doi.org/10.12691/ education-4-7-10

[29] Van Deusen, J. E. (2009). Factors influencing happiness in women religious. (Master's thesis, St. Mary University of Minnesota). 